\title{
PROFITABILITY AND OPTIMAL DEBT LEVEL OF LARGE FIRMS IN SERBIA
}

\author{
Milošev Ivana ${ }^{1}$
}

Summary: The aim of this research is to analyse the impact of debt management on the profitability of firms. The research was conducted for a five-year period from 2016 to 2020, on a sample of 299 large non-financial firms in Serbia. The Generalized Method of Moments (GMM) is used to examine the ratio of the share of total debt in total assets to the profitability expressed through the ROA indicator. The first thing considered is the linear relationship between indebtness and profitability followed by the nonlinear relationship between indebtness and profitability. The results of research show that there is a statistically significant correlation and a linear, negative ratio of indebtedness indicators in relation to the profitability of the observed firms. The results of the study do not show a nonlinear (concave) relationship. They show both negative and statistically significant impact of tangibility on the profitability of large companies in Serbia, while company size and inflation do not have a significant impact on profitability.

Key words: indebtedness / profitability of firms in Serbia / GMM.

\section{INTRODUCTION}

Profitability is the central indicator of a company's performance. The optimal level of profitability measures the long-term success and thus its

\footnotetext{
${ }^{1}$ Faculty of Economics, Segedinski put 9-a, 24000 Subotica, e-mail: ivana79.milosev@gmail.com
} 
survival. Since the Modigliani and Miller paper (1958), numerous researches have focused on ways to increase companies' profitability. There is no universal formula to explain why profitability varies among them and whether the optimal debt level exists or not.

There are numerous theories about optimizing the capital structure. Different views on the impact of debt management on a company performance have been noted in papers. Modigliani and Miller (1958) argue that the capital structure is irrelevant. The MM theory assumes that firms operate in a perfect capital market and that there is no taxation of profits implying that the choice of debt or capital has no impact on the capital expenses, i.e., the value of a firm is unaffected by how that firm is financed. The revised MM theory (Modigliani \& Miller, 1963 ) indicates that the level of debt is relevant. Firms with better access to loans are rather privileged in terms of maximizing their value due to the tax shield, but this does not mean that firms should strive to use the maximum amount of debt in their sources of financing.

The trade-off theory of capital structure (Myers, 1984) argues that the capital structure is formed as a compromise between the benefits and costs of debt and one's capital, while taking into account market imperfections such as tax, bankruptcy, and agent expenses. Ross (1977) introduces the Incentive-Signalling Approach in the study of capital structure stating that a firm's value grows with the growth of financial leverage. The growth of leverage increases the market perception of value. Thus, regarding the asymmetric management information in relation to the market, an issue of debt will be perceived positively. Myers and Majluf in the Pecking order theory (1984) argue that there is no optimal or targeted structure of financial leverage. Authors Baker and Wurgler (2002), creators of the Market timing hypothesis, believe that "the current capital structure is the cumulated result of past attempts related to the capital market."

These theories are important for capital structure and imply certain relations which are expected among leverage and profitability. Enterprise indebtedness is important both at the enterprise level and the macroeconomic level due to its impacts. The business operations of firms in the real sector in Serbia are characterized by a high level of liabilities in relation to assets and equity, and an orientation towards 
external sources of financing. Guided by the research of Kebewar (2013) and Ngo et. al. (2020), the aim of this paper is to answer to following question: What are the impacts of debt management on the profitability of large non-financial firms in Serbia?

Section 2 of this paper presents a review of the literature dealing with the relationship between debt management and profitability. Section 3 presents an analysis of the profitability of large businesses in Serbia and relevant market trends as a basis for the hypotheses. Section 4 presents the research methodology, sample description, and definition of the observed variables. Validation of the model with discussion of the obtained results are presented in Section 5. Section 6 is the conclusion.

\section{THEORETICAL AND EMPIRICAL BACKGROUND}

The relationship between debt and company profitability is one of the popular topics in the corporate finance literature. The importance and impact of indebtedness on a company's profitability has contributed to empirical research that has been going on for several decades. So far, no consensus has been reached on the debt-to-profitability ratio. The following is a summary of empirical research in chronological order starting with the latest papers (Table 1).

Most papers that focus on quantifying the impact of indebtedness on profitability use panel data analysis with, GMM, FE or OLS assessment techniques, but the results are contradictory.

Some papers show a statistically significant, linear, and negative relationship between debt management and profitability such as the listed companies in Romania (Vătavu, 2014), non-financial companies in Serbia (Stančić, Janković and Čupić, 2016) where the research shows a negative effect of indebtedness (long-term debt) on profitability (Return on Assets). Stryckova (2017) finds negative effect of debt ratio and ROE on the example of Czech firms. Andersson and Minnema (2018) on the example of Swedish consulting firms show a negative effect of debt (short-term, long-term and total indebtedness) on profitability. 
Table 1 -Literature review

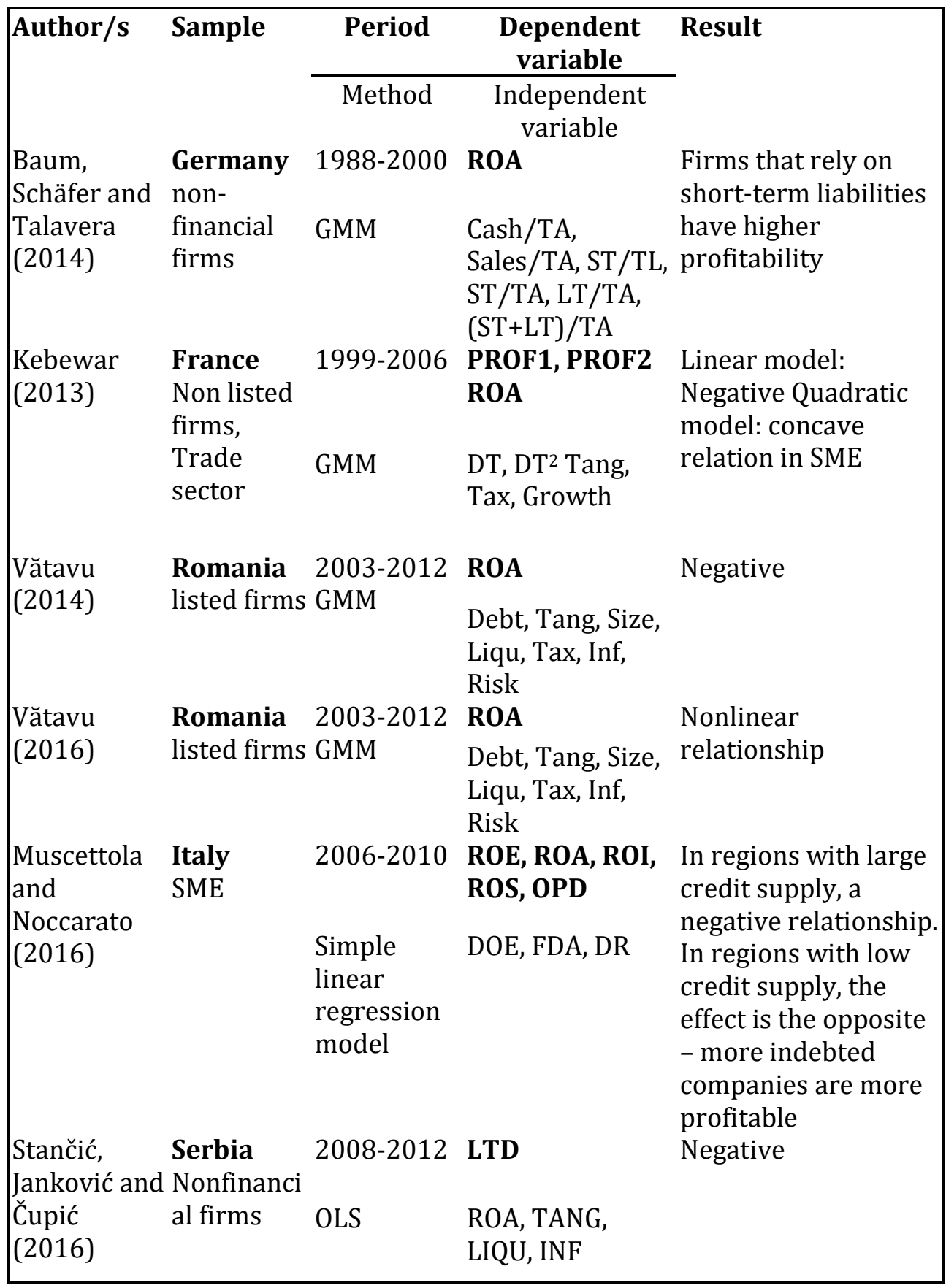




\begin{tabular}{|c|c|c|c|c|}
\hline $\begin{array}{l}\text { Anderson } \\
\text { and } \\
\text { Minnema } \\
(2018)\end{array}$ & $\begin{array}{l}\text { Sweden } \\
\text { Consulting } \\
\text { firms }\end{array}$ & $\begin{array}{l}\text { 2012-2016 } \\
\text { OLS and FE }\end{array}$ & $\begin{array}{l}\text { TDA, STA, LDA, } \\
\text { SIZE, LIQU, AGE }\end{array}$ & Negative \\
\hline Raharja and & & $1999-2018$ & EAT & Quadratic model: \\
\hline $\begin{array}{l}\text { Mranani } \\
(2019)\end{array}$ & $\begin{array}{l}\text { Indonesia } \\
\text { Listed } \\
\text { firms }\end{array}$ & $\begin{array}{l}\text { Polynomial } \\
\text { regression } \\
\text { analysis }\end{array}$ & $\begin{array}{l}\text { TD TD2 SIZE } \\
\text { EAT-1 }\end{array}$ & $\begin{array}{l}\text { concave, nonlinear } \\
\text { relationship. } \\
\text { Indebtedness has a } \\
\text { positive effect on } \\
\text { profitability up to a } \\
\text { certain level after } \\
\text { which it is } \\
\text { counterproductive. }\end{array}$ \\
\hline Basdekis, & & $2005-2017$ & ROE & Quadratic model: \\
\hline $\begin{array}{l}\text { Christopoul } \\
\text { os, } \\
\text { Katsampoxa } \\
\text { kis and } \\
\text { Lyras } \\
(2020)\end{array}$ & $\begin{array}{l}\text { EU } \\
\text { Car } \\
\text { industry }\end{array}$ & EGLS & $\begin{array}{l}\text { DR DR }{ }^{2} \text { GDPGR } \\
\text { SIZE ACCRUALS } \\
\text { ECBRATE EAESI }\end{array}$ & $\begin{array}{l}\text { concave, nonlinear } \\
\text { relationship. } \\
\text { Indebtedness has a } \\
\text { positive effect on } \\
\text { profitability up to a } \\
\text { certain level after } \\
\text { which it is } \\
\text { counterproductive. }\end{array}$ \\
\hline $\begin{array}{l}\text { Ngo, Tram } \\
\text { and Vu } \\
(2020)\end{array}$ & $\begin{array}{l}\text { Vietnam } \\
\text { Listed } \\
\text { nonfinanci } \\
\text { al firms }\end{array}$ & $\begin{array}{l}\text { 2009-2017 } \\
\text { GMM }\end{array}$ & $\begin{array}{l}\text { PROF } \\
\text { (EBIT/TA) } \\
\text { DT DT2 SIZE } \text { TANG TAX } \\
\text { GROWTH }\end{array}$ & $\begin{array}{l}\text { Linear model: } \\
\text { negative impact of } \\
\text { debt on profitability } \\
\text { Quadratic model: } \\
\text { concave relation, } \\
\text { nonlinear relation } \\
\text { statistically } \\
\text { significant in SME }\end{array}$ \\
\hline
\end{tabular}

Source: Author

Some authors did not establish a negative effect of indebtedness on profitability. Muscettola and Noccarato (2016) confirm the impact of credit supply on the samples of SME in Italy. The high credit supply creates a negative effect of debt on profitability, whereas the low credit supply creates a positive effect. Baumm, Schäfer and Talavera (2014) show a positive effect of a short-term debt to profitability on the example of German non-financial firms. Kebewar (2012) shows on the example of French service firms that the indebtedness has no impact on profitability. 
Kebewar (2013) also shows that indebtedness can have a linear or nonlinear impact on profitability using the sample of French unlisted companies from the trade sector. Linear model: negative impact of debt on profitability. Quadratic model: concave, nonlinear, and statistically significant relationship in small and medium enterprises. This research is in line with the research of Ngo, Tram and Vu (2020) on the example of listed firms in Vietnam, the research of EU car companies (Basdekis et al., 2020) and the research of listed companies in Indonesia (Raharja and Mranani, 2019).

\section{PROFITABILITY OF LARGE COMPANIES IN SERBIA}

The profitability, measured by the rate of Return on Assets (ROA) of businesses in real sector in Serbia in 2020 was 3.0\%. The positive trend in the period from 2014 to 2018 was interrupted in 2019 but recorded a slight increase in 2020. According to the data of the Serbian Business Registers Agency [hereinafter SBRA] (2021, pp11) ROA was 1.6\%, 2.5\%, $3.4 \%, 4 \%, 2.9 \%$ and 3\% respectively in the period $2015-2020$.

Large companies in Serbia, although few in number, have a significant impact on the economic parameters. Large systems, as generators of economy, achieved a $41.2 \%$ market share in the realized incomes in 2020 and participate with $43.3 \%$ of Total Assets and $50.2 \%$ of the Total Equity in Serbian economy (2021, pp24).

Serbian economy is recording an increasing trend in total liabilities and indebtedness. In the past five years, total liabilities increased by $7 \%$, total liabilities have grown at an average annual rate of $1.7 \%$ (Statistical Office of the Republic of Serbia, 2020, pp71). The indebtedness continues to grow in 2020, among other things, as a consequence of measures aimed at combating the negative effects caused by the coronavirus pandemic in the form of stimulated loans from the guaranteed scheme and loans for liquidity and working capital (SBRA, 2021, pp13). According to the SBRA (2021, pp6) the total liabilities of real sector in 2020 amount to RSD $10,778.8$ billion which is an increase of $10.4 \%$ compared to the previous year. One third of the liabilities belong to large companies. Liabilities tend to increase faster (increase of 10.4\%) than capital (increase of $4.7 \%$ ) in 2020 (SBRA, 2021, pp13). According to the SBRA (2021, pp13) 
the trend is to finance businesses' activities at the expense of suppliers. The indebtedness trend (ratio of total debt and total assets) of real sector and large companies in the observed period is shown in Figure 1 . The average debt ratio (DR) of the real sector is $61 \%$ in the observed fiveyear period.

Figure 1. Debt (DR) in real sector and large companies in Serbia

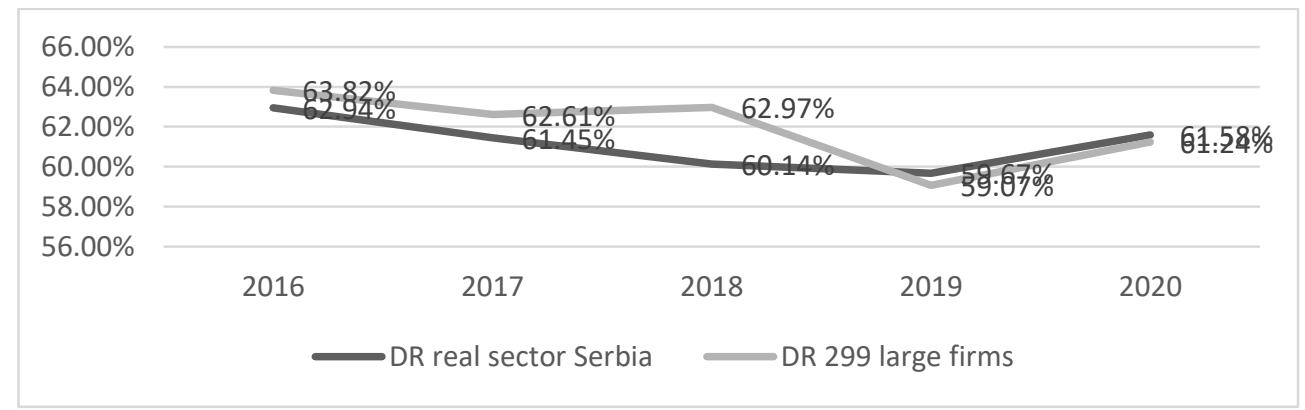

Source: Author's calculation based on data by SBRA

The Return on Asset (ROA) trend in Serbian economy and large enterprises in the observed period is shown in Figure 2. The ROA of the real sector in Serbia in average is $3.16 \%$. The ROA indicator of profitability of 299 large companies in Serbia varies in the observed period, but it is higher than the real sector average (SBRA, 2021).

Figure 2 ROA in real sector and large companies in Serbia

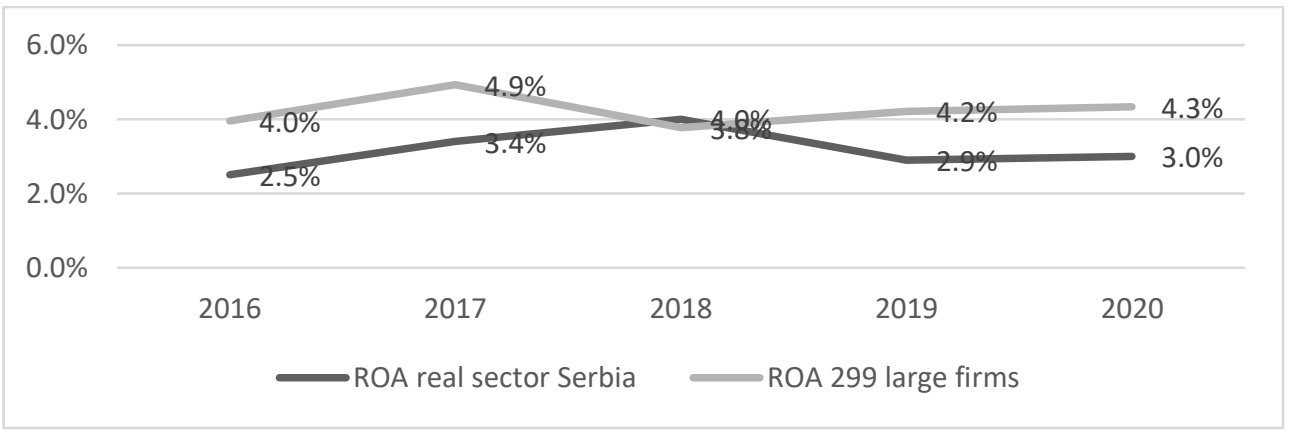

Source: Authors'calculation based on data by SBRA 


\section{DATA AND METHODOLOGY}

The subject of this paper is the analysis of the impact of debt trends on the profitability of large firms in Serbia for the period from 2016 to 2020 in order to determine whether debt management in the observed period contributes to higher profitability. The companies included in the analysis are active, non-financial companies for which there are available financial data for the period from 2016 to 2020 on the date of data collection and which are classified as large companies in 2020 in accordance with Article 6 of the Law on Accounting (Law on Accounting, Official Gazette of the RS, 2019). Large companies are businesses that meet two of the three criteria: average number of employees 250, revenue EUR 40,000,000 converted in RSD and the value of total assets at the balance sheet date EUR 20,000,000 converted in RSD. According to the data of the Serbian Business Registers Agency, there were 422 large companies in Serbia in 2020, but only 299 of them met the stated criteria, so the sample includes 299 large companies. These enterprises were selected due to its importance to the Serbian economy. Large companies achieve $41.2 \%$ market share in total real economy revenues in 2020 (SBRA, 2021, p. 24). The data set for the analysis was done using the database SBRA. However, the final database was put together manually, computed, and constructed by the author, including manual calculation of ratios. The sample includes 299 firms $(\mathrm{N}=299)$ and a fiveyear period $(\mathrm{T}=5)$ which resulted in total of 1,495 observations for the study.

The selection of dependent and independent variables was made on the basis of literature analysis. Profitability is a dependent variable in this research, most commonly measured using ROE and ROA. In this research, Return on Assets $(\mathrm{ROA})=$ Net profit $/$ Total Asset was selected. The study is based on the debt ratio (DR), leading variable for debt management and is defined as (DR) = (Total debt: long term + short term) $/$ Total asset, according to the research (Kebewar, 2013; Ngo, Tram and Vu, 2020; Basdekis et al., 2020 and Raharja and Mranani, 2019). In line with the previous research (Kebewar, 2013; Ngo, Tram and Vu, 2020; Basdekis et al., 2020 and Raharja and Mranani, 2019) quadratic model was analysed to examine nonlinear impact of debt on profitability. This study introduces another independent variable square debt ratio $\left(\mathrm{DR}^{2}\right)$. 
Based on the previously conducted studies, control variables are included in the model in order to improve it and to explain the profitability of large firms in Serbia that are not captured by debt ratio. The Asset Size Indicator (Size) is the natural logarithm of an asset and expresses the impact of asset size on a company's profitability. In the results of research by many authors, there is no clear consensus regarding the relationship between asset size and profitability. Kebewar (2013) and Basdekis at al. (2020) found that there is no relationship between size and profitability while the authors Gabrijelčić at al. (2013), Andersson and Minnema (2018) and Ngo at al. (2020) found a positive relationship which implies that larger firms achieve higher productivity. The control variable is also the tangibility of assets (TANG): total tangible assets / total assets. Authors Stančić, Janković Čupić (2016) show a negative ratio in production facilities but not in service firms, authors Vătavu (2014) and Ngo et al. (2020) found a negative relationship between tangibility and profitability. The third control variable is inflation. The data on the inflation rate was taken from the report of the National Bank of Serbia (NBS, 2021) in order to take into account, the impact of the macroeconomic environment during the observed five-year period. Inflation in this study is presented as the INF variable. Research has shown that inflation may have a negative influence on profitability (Vătavu, 2014) and also that there is no impact on profitability (Stančić et al., 2016).

The aim of the analysis is to prove or disprove the hypotheses formulated by the research:

H1: There is a linear and negative correlation between debt management (DR) indicators and firms' profitability.

H2: There is no linear relationship between debt management indicators (DR) and the profitability, but the optimal level, above which profitability of firms decreases.

As a research method, dynamic panel analysis is widely used in economic research in which the current value of a variable, for example ROA, depends on the value of the same variable from previous periods. The optimal choice is a dynamic model because the autocorrelation, i.e., a situation in which relation errors in time $t$ affect relation errors in time $\boldsymbol{t + 1}$, is not included in the assumptions of static models. The following 
empirical model is formulated to analyse the influence of debt management on the profitability of the observed enterprises:

ROA $_{i, t}=\beta_{0}+\beta_{1} \mathrm{DR}_{\mathrm{i}, \mathrm{t}}+\beta_{2}$ Size $_{\mathrm{i}, \mathrm{t}}+\beta_{3}$ Tang $_{\mathrm{i}, \mathrm{t}}+\beta_{4} \mathrm{INF}_{\mathrm{i}, \mathrm{t}}+\beta_{5} \mathrm{ROA}_{\mathrm{i}, \mathrm{t}-1}+\sum^{5} \mathrm{n}=1 \beta_{\mathrm{n}}$ $d_{u m t_{\mathrm{n}}}+\mathrm{n}_{\mathrm{i}}+\varepsilon_{\mathrm{i}, \mathrm{t}}$

where $\boldsymbol{i}$ represents the number of observed firms in Serbia ( $\mathrm{i}=1 \ldots 299)$ and $t$ represents the time period 2016-2020 ( $\mathrm{t}=1 \ldots 5)$. The dependent variable is profitability (ROA), the independent variable is the debt ratio (DR), while Size, Tang and INF represent the control variables of size, tangibility, and inflation. The presence of the dependent variable from the previous period $\left(\mathrm{ROA}_{\mathrm{i}, \mathrm{t}-1)}\right)$ as an independent variable in the dynamic model allows control of bias and inconsistency. The time influence is taken into account by introducing a binary (dumt) variable that takes into consideration the specific effect of the year (2016-2020). The regression coefficients with independent variables are $\beta$, the individual fixed effect of the firms is $n_{i}$ and $a \varepsilon$ it is a random error.

A quadratic model that takes into account the square of the debt ratio in the regression equation was applied in order to examine the nonlinear relationship between debt and profitability:

ROA $_{i, t}=\beta_{0}+\beta_{1} D_{i, t}+\beta_{2} D^{2}{ }_{i, t}+\beta_{3}$ Size $_{i, t}+\beta_{4}$ Tang $_{i, t}+\beta_{5}$ INF $_{i, t}+\beta_{6}$ $\mathrm{ROA}_{\mathrm{i}, \mathrm{t}-1}+\sum_{\mathrm{n}=1}^{5} \beta_{\mathrm{n}} d u m t_{\mathrm{n}}+\mathrm{n}_{\mathrm{i}}+\varepsilon_{\mathrm{i}}$

Hypothesis 1 tests a linear effect where the coefficient $\beta_{1}$ is 0 .

Hypothesis 2 tests a non-linear effect where high debt ratio should have positive values.

\section{ANALYSIS, RESULTS AND DISCUSSION}

The research covers the period from 2016 to 2020. The data sources used in the research are the financial statements obtained from the SBRA. However, the final database as well as the ratio analysis, was compiled manually, computed, and made by the author.

The results of descriptive statistics for the sample are shown in Table 2. The table shows the average values, standard deviation, minimum and maximum values of the observed variables. These variables comprise data from 1,495 observations. ROA is a dependent and a central variable for 
answering the research question. Most theories believe that a good level of profitability for ROA is greater than $10 \%$. The statistics show that the average profitability of large enterprises (ROA) in Serbia in a period of five years is 0.0358 or $3.58 \%$ which can be considered low profitability. The average ROA values were adjusted after applying the Winsorizing method in STATA due to extreme values. The value of ROA is comparable to the ratios presented by listed firms in Romania 3.9\% (Vătavu, 2016) and below those recorded in the trade sector in France 5.8\% (Kebewar, 2013), listed firms in Vietnam 8.02\% (Ngo et al., 2020) and the car industry in EU $14.4 \%$ (Basdekis et al., 2020). The average value of debt ratios for large Serbian firms is $59.17 \%$ with a standard deviation 0.3768 . The average values of DR were further adjusted as an effect of limiting the maximum value to 2.3665 and minimum to 0.0514 by using the Winsorizing method in STATA for outliers ( $99^{\text {th }}$ and $1^{\text {st }}$ percentile). The pre-adjusted values for ROA and DR, before using the Winsorizing method in STATA, can be seen in Appendix 1. The size of the observed large firms measured as the natural logarithm of assets averages is $15.70 \%$ yearly, tangibility is $46.98 \%$ and inflation on average is $1.93 \%$.

Table 2 Descriptive statistics for the sample

\begin{tabular}{|c|c|c|c|c|c|}
\hline Variable & Obs & Mean & Std. Dev. & Min & Max \\
\hline ROA_wi & 1495 & .0358012 & .1175785 & -.6004202 & .3682075 \\
\hline DR_wi & 1495 & .5917819 & .3768044 & .0514122 & 2.36651 \\
\hline Size & 1495 & 15.70922 & 1.141661 & 12.64528 & 20.72844 \\
\hline Tang & 1495 & .4698222 & .2616035 & .0010055 & .9989492 \\
\hline INF & 1495 & .193804 & .0059353 & .0125136 & .0300625 \\
\hline
\end{tabular}

Source: Authors' calculation based on STATA Statistics v.12.0

The correlation between the observed independent variables is examined first in order to detect a possible problem of multicollinearity that can cause disturbances in the assessment of parameter values, their significance and impact on the dependent variable ROA. The Pearson correlation matrix for the variables is presented in Table 3. Analyzing the correlation matrix, all the statistically significant correlations are of low intensity. In relation to the ROA, statistically significant, negative and moderate correlation with debt ratio (DR) and statistically significant, 
positive and low correlation with a firm's size (Size) was noted as well as negative and low correlation with tangibility (Tang); positive and weak correlation with inflation (INF). The correlation between tangibility and size is positive, moderate, and significant. While correlation of debt and the firm size and debt and tangibility is significant, moderate, and negative.

Table 3 Pearson correlation coefficient

\begin{tabular}{|c|c|c|c|c|c|}
\hline & ROA_wi & DR_wi & Size & Tang & INF \\
\hline ROA_wi & 1.0000 & & & & \\
\hline \multirow{2}{*}{ DR_wi } & $\begin{array}{c}-0.4069^{*} \\
0.0000\end{array}$ & 1.0000 & & & \\
\hline \multirow{2}{*}{ Size } & $0.0010^{*}$ & $-0.1348^{*}$ & 1.0000 & & \\
\hline \multirow{2}{*}{ Tang } & 0.9680 & 0.0000 & & & \\
\hline \multirow{2}{*}{ INF } & -0.0494 & $-0.2519^{*}$ & $0.4116^{*}$ & 1.0000 & \\
& 0.0562 & 0.0000 & 0.0000 & & \\
\hline
\end{tabular}

* Statistical significance at the level of $5 \%$. Source: Authors' calculation based on STATA Statistics v.12.0

Thus, the precondition for the use of the regression model is the absence of multicollinearity between independent variables. Although this is visible in the Pearson correlation matrix, in order to test the multicollinearity, the author chose to construct a correlation matrix and to conduct the VIF test in STATA. As there is no correlation between two variables that exceed 10 and $1 / \mathrm{VIF}$ is not below 0.2 , it can be concluded that there is no multicollinearity in the model.

Table 4 VIF test of multicollinearity

\begin{tabular}{|c|cc|}
\hline Variable & VIF & 1 / VIF \\
\hline Tang & 1.26 & 0.791133 \\
Size & 1.21 & 0.828483 \\
DR_wi & 1.07 & 0.935096 \\
INF & 1.00 & 0.998333 \\
\hline Mean VIF & 1.14 & \\
\hline
\end{tabular}

Source: Authors' calculation based on STATA Statistics v.12.0 
A problem of serial correlation (DW=1.136655) and heteroskedasticity in the model occur (BP Prob $>F=0.000$ and F (5.1489) = 20.62). The GMM method was applied to work around the heteroskedasticity and the endogeneity problem. As suggested by Roodman (2009, pp102) the endogeneity problem was corrected by the instrumental variables ROAi, $t-1$.

We use linear and nonlinear models to evaluate the relation between dependent (ROA) and independent variable (DR). The results are shown in Tables 5 and 6. The models show that there is no second order of autocorrelation $\operatorname{AR}(2)$ and that instruments in our model are valid (the Hansen test).

In the linear model, the results show a negative, linear, and significant impact of debt ratio on profitability and support H1. The results are in line with the results obtained by analysing trade firms in France (Kebewer, 2013), listed firms in Vietnam (Ngo et. al., 2020), firms in the car industry, cement, and sugar sectors in Pakistan (Nazir et. al., 2021), Swedish consulting companies (Andersson and Minnema, 2018), large companies in Serbia (Stančić et. al., 2016), and listed companies in Poland (Anton and Nucu, 2020).

The results of the quadratic model show that coefficient $\beta_{1}$ and $\beta_{2}$ for DR and $\mathrm{DR}^{2}$ are negative and do not support the $\mathrm{H} 2$ (that $\mathrm{DR}^{2}$ has positive values). The analysis of the trade firms in France (Kebewar 2013, pp10) also did not show nonlinear relation within large firms, only with SME. On the other hand, the quadratic model, concave, and nonlinear relationship are shown in analysis of the listed companies in Indonesia (Raharja and Mranani, 2019), EU car industry (Basdekis et. al., 2020), and the listed companies in Vietnam (Ngo et. al., 2020). In this research, indebtedness has a positive impact on profitability up to a certain level after which it is counterproductive.

Asset tangibility (TANG) shows a negative and statistically significant impact on profitability (ROA), also confirmed by Vătavu (2014), Ngo et. al. (2020) and Stančić et. al. (2016) but only within production facilities, while Kebewar shows positive impact of tangibility on profitability with small and medium sized companies. The size potential (Size) has a positive but not statistically significant impact on profitability (Anderson and Minnema, 2018; Nazir et. al., 2021; Basdekis et. al., 2020), the inflation also has positive but not statistically significant impact on 
profitability (Stančić et. al, 2016), while the listed firms in Romania (2016) show nonlinear relationship between inflation and profitability.

Table 5 Results of GMM - linear model

\begin{tabular}{|c|c|c|c|}
\hline \multirow{2}{*}{\begin{tabular}{|l|} 
ROA_wi \\
Independent \\
variable \\
\end{tabular}} & \multicolumn{3}{|c|}{ Model two step system GMM } \\
\hline & Coef. & $\begin{array}{c}\text { Corrected } \\
\text { Std. Err. }\end{array}$ & $P>|t|$ \\
\hline ROA_wi_l1 & .260393 & .1122953 & $0.021^{*}$ \\
\hline DR_wi & -.0800185 & 0.199541 & $0.000^{* * *}$ \\
\hline Size & .0015555 & .0035629 & 0.663 \\
\hline Tang & -.0419463 & .0137982 & $0.003^{* *}$ \\
\hline INF & .6456323 & .3748868 & 0.086 \\
\hline No of observations & 1196 & $F(7,298)$ & 68.01 \\
\hline No of groups & 299 & Prob $>$ F & 0.000 \\
\hline No of instruments & 11 & AR(2) & 0.381 \\
\hline Year Dummies & Yes & Hansen test & 0.447 \\
\hline Obs per group & 4 & & \\
\hline
\end{tabular}

Note: ${ }^{*}$ Statistical significance at the level of $5 \%$; ${ }^{* *}$ of $1 \%$; ${ }^{* * *}$ of $0.1 \%$. Each equation includes year as dummy variables. $p$-values are expressed for AR (2) and Hansen statistic. Hansen test is Saragan-Hansen test. AR (2) is test for the second level of autocorrelation. Estimations of the two-step GMM System. Instruments (ROA_wi_I1 as 1 year lag, other variables DR, DR ${ }^{2}$, Size, Tang and INF are exogenous). Source: Authors' calculation based on STATA Statistics v.12.0

Table 6 Results of GMM - nonlinear model

\begin{tabular}{|c|c|c|c|}
\hline \multirow{2}{*}{$\begin{array}{l}\text { ROA_wi } \\
\text { Independent } \\
\text { variable }\end{array}$} & \multicolumn{3}{|c|}{ Model two step system GMM } \\
\hline & Coef. & $\begin{array}{l}\text { Corrected } \\
\text { Std. Err. }\end{array}$ & $P>|t|$ \\
\hline ROA_wi_l1 & .2853832 & .1122744 & $0.012^{*}$ \\
\hline DR_wi & -.0624745 & .017407 & $0.000^{* * *}$ \\
\hline $\mathrm{DR}^{2}$ & -.002682 & .0006337 & $0.000^{* * *}$ \\
\hline Size & .0009667 & .0033745 & 0.775 \\
\hline Tang & -0380962 & .0132224 & $0.004^{* *}$ \\
\hline INF & .5729852 & .372428 & 0.125 \\
\hline No of observations & 1196 & $F(8,298)$ & 69.90 \\
\hline No of groups & 299 & Prob $>$ F & 0.000 \\
\hline No of instruments & 12 & $\mathrm{AR}(2)$ & 0.219 \\
\hline Year Dummies & Yes & Hansen test & 0.367 \\
\hline Obs per group & 4 & & \\
\hline
\end{tabular}

* Statistical significance at the level of $5 \%$; ** of $1 \%$; *** of $0.1 \%$. Each equation includes years as dummy variables. p-values are expressed for AR (2) and Hansen statistics. The Hansen test is the Saragan-Hansen test. AR (2) is a test for the second level of autocorrelation. Estimations of the two-step GMM System. Instruments (ROA_wi_I1 as 1 year lag, other variables DR, DR ${ }^{2}$, Size, Tang and INF are exogenous). Source: Authors' calculation based in STATA Statistics v.12.0 


\section{CONCLUSION}

The conclusion on the optimal relationship of debt and profitability are not consistent in the empirical studies. The results of this study on a sample of large firms in Serbia in a five-year period (2016-2020) indicate that debt management, measured by share of total debt in total assets, has statistically significant, negative, and linear influence of profitability. The increased level of debt of large companies in Serbia decreases profitability. The results support the capital structure theory by Myers and Majluf (1984) which states that internal financing leads to a reduced level of indebtedness and negative relations to profitability.

The second hypothesis which states there is no linear relationship between debt management (DR) and profitability is not confirmed.

Tangibility and profitability have a significant and negative relationship. Enterprise size potential and inflation have a positive but not statistically significant influence on profitability. Many internal factors affect a firm's business performance, and their recognition can significantly improve the business performance.

Large companies in Serbia, although few in number, have a great influence on economic parameters and are generators of Serbian economy. They participate with $41.2 \%$ in total realized revenues of the Serbian economy in 2020 and employ 32\% of workers (SBRA, 2021, pp9 and pp24). They have an average profitability of 0.0358 in the observed five-year period which indicates that on average only $3.58 \%$ of company assets are retained as net profit.

Further research might take into consideration more determinations of profitability that have a significant influence on profitability and are not included in this model. Also, future research can take into account sector analysis and longer observation periods as well as SME analysis. As the economy is affected by Covid-19 (the coronavirus), future research may be focused on examining the speed of adjustment and/or recovery of debt management during the financial crisis or pandemic period. 


\section{REFERENCES}

1. Adair, P. \& Adaskou, M. (2015). Trade-off theory vs. Pecking order theory and the determination of corporate leverage: Evidence from a panel data analysis upon French SMEs (2002-2010). Cognet Economics \& Finance, 3:1, 1006477, DOI: 10.1080/ 23322039.2015.1006477

2. Andersson, A. \& Minnema, J. (2018). The relationship between leverage and profitability, A quantitative study of consulting firms in Sweden. Umea School of Business, economics and statistics.

3. Anton, S. G. \& Nucu, A. E. A., (2020). The Impact of Working Capital Management on Firm Profitability: Empirical Evidence from Polish Listed Firms. Journal of Risk and Financial Management, 14,9, https://dx.doi.org/10.3390/jrfm14010009, 2-14.

4. Baum, C., Schäfer \& D. \& Talavera, O. (2006). The effects of shortterm liabilities on profitability: the case of Germany, DIW Berlin, German Institute for Economic Research, Discussion Paper nr. 635.

5. Basdekis. C., Christopoulos. A., Katsampoxakis. I. and Lyras. A. (2020). Profitability and optimal debt ratio ot the automobiles and parts sector in the Euro area, Journal of Capital Markets Studies, 4 (2), 113-127, DOI 10.1108/JCMS-08-2020-0031.

6. Gabrijelčić, M., Herman, U. and Lenarčić, A. (2013). Debt financing and firm performance before and during the crisis: micro-financial evidence from Slovenia. European Stability Mechanism Research Paper, 15.

7. Jakšić, D., Zekić, S., Ristić, M. and Mijić, K. (2016). Profitabilnost poljoprivrednih preduzeca u zemljama Jugoistocne Evrope. Agroekonomika, 71, 1-11.

8. Kebewar, M. (2012). The effect of debt on corporate profitability Evidence from French service sector. Laboratoire d'Econmie d'Orleans- UMR CNRS 7322 Faculte de Droit, B.P. 26739-45067 Oreans Cedex 2- France.

9. Kebewar, M. (2013). Does debt affect profitability? An empirical study of French trade sector. Humanities and Social Sciences/Economics and Finance, HAL Id: halshs-00780310 https://halshs.archives-ouvertes.fr/halshs-00780310 
10. Modigliani F., Miller M. H. (1963). Corporate Income Tax and the Cost of Capital: A Correction. The American Economic Review, 53(3), 433-443

11. Modigliani, F., \& Miller, M. H. (1958): The Cost of Capital, Corporation Finance and the Theory of Investment, The American Economic Review, 48(3), 261-297.

12. Myers, S. C., \& Majluf, N. S. (1984). Corporate Financing and Investment Decisions When Firms Have Information That Investors Do Not Have. NBER Working Paper Series, Working Paper, 1396.

13. Myers, S. C. (1984). The Capital Structure Puzzle. The Journal of Finance, 39(3), 575-592.

14. Muscettola, M. \& Naccarato, F. (2016). The Casual Relationship Between Debt and Profitability: The Case of Italy. Athens Journal of Business and Economics, 2(1), 17-32

15. National Bank of Serbia (2021, Jun 21) nbs.rs, Preuzeto sa: https://nbs.rs/sr/drugi-nivo-navigacije/publikacije-iistrazivanja/IOI/.

16. Nazir, A., Azam, M., i Khalid, M.U. (2021). Debt financing and firm performance: empirical evidence from the Pakistan Stock Exchange. Asian Journal of Accounting Research, Emerald Publishing Limited 2443-4175. DOI 10.1108/AJAR-03-2019-0019.

17. Ngo, V. T. \& Tram, B. T (2020). The Impact of Debt on Corporate Profitability: Evidence from Vietnam. Journal of Asian Financem Economics and Business, 7 (11), 5-842. doi:10.13106/jafeb.2020.vol7.no11.835

18. Raharja, B. S. \& Mranani. M (2019). The Nonlinear Effect of Debt on Firm Performance, Journal Ekonomi Malaysia 53(3) 3-9, http://dx.doi.org/10.17576/JEM-2019-5303-1.

19. Ross, S. A. (1977). The Determination of Financial Structure: The Incentive Signalling Approach, Bell Journal of Economics, 8(1), 23-40.

20. Roodman, D. (2009). How to do xtabond2: An introduction to difference and system GMM in Stata, The Stata Journal, 9(1), 86136.

21. Serbian Business Registers Agency (2018, March 21), Financial Statements Annual Bulletin 2017, Preuzeto sa:

https://www.apr.gov.rs/upload/Portals/0/GFI\%202018/Bilten20 17.pdf. 
22. Serbian Business Registers Agency (2020, May 21), Financial Statements Annual Bulletin 2019, Preuzeto sa:

https://www.apr.gov.rs/upload/Portals/0/GFI_2020/Makroekon omska_saopstenja/Godisnji_izvestaj_o_poslovanju_privrede_u_201 9.pdf.

23. Serbian Business Registers Agency (2021, Jul 21), Financial Statements Annual Bulletin 2020, Preuzeto sa: https://www.apr.gov.rs/upload/Portals/0/GFI_2021/Makroekon omska_saopštenja/Godišnji_izvestaj_o_poslovanju_privrede_u_202 $0 . p d f$.

24. Sl. Glasnik RS, 2019, Zakon o računovodstvu (2019, Jun 2021), Preuzeto sa: https://www.paragraf.rs/propisi/zakon-oracunovodstvu-2020.html.

25. Stančić P., Janković M. i Čupić M. (2016). Testing the relevance of alternative capital structure theories in Serbian economy, Teme, 40 (4), 1309-1325.

26. Statistical Office of the Republic of Serbia (2020, March 21), Trendovi, Performanse poslovanja provrede Republike Srbije 2015-2019, Accessed: https://publikacije.stat.gov.rs/G2020/Pdf/G20208003.pdf.

27. Stryckova L. (2017). The Relationship Between Company Returns and Leverage Depending on the Businss Sector: Empirical Evidence from the Czech Republic, Journal of Cpmpetitiveness, 9(3), 98-110.

28. Vătavu, S. (2014). The determinants of profitability in companies listed on the Bucharest Stock Exchange, Annals of the University of Petrosani, Economics, 14(1), 329-338.

29. Vătavu, S. (2016). Non-linear panel data analysis for capital structure and its impact on profitability. The Review of Finance and Banking, 8 (1), 021-036. 
Appendix no 1. Minimum and maximum values before and after Winsorized adjustment

\begin{tabular}{|c|c|c|c|c|}
\hline \multirow{2}{*}{} & \multicolumn{2}{|c|}{ All observations } & \multicolumn{2}{c|}{ Extreme values excluded } \\
\cline { 2 - 5 } & Min & Max & Min & Max \\
\hline ROA & -2368.346 & 3.364722 & -.6004202 & .3682075 \\
\hline DR & .0293719 & 13.34359 & .0514122 & 2.36651 \\
\hline Size & 12.64528 & 20.72844 & 12.64528 & 20.72844 \\
\hline Tang & .0010055 & .9989492 & .0010055 & .9989492 \\
\hline INF & .0125136 & .0300625 & .0125136 & .0300625 \\
\hline
\end{tabular}

Source: Authors' calculation based on STATA Statistics v.12.0

\title{
PROFITABILNOST I OPTIMALNI NIVO DUGA KOD VELIKIH PREDUZEĆA U SRBIJI
}

\author{
Milošev Ivana
}

Sažetak: Cilj rada je analiza uticaja upravljanja dugom na profitabilnost preduzeća. Istraživanje je spovedeno za petogodišnji period od 2016. do 2020. godine, na uzorku 299 velikih nefinansijskih preduzeća u Srbiji. Primenom dinamičkog panela generalizovanom metodom momenata (GMM) ispitan je odnos učešća ukupnog duga u ukupnoj imovini na profitabilnost preduzeća izražene kroz ROA pokazatelj. Prvo je istraženo da li postoji linearan odnos zaduženosti $i$ profitabilnosti, zatim je istraženo da li postoji nelinearan odnos zaduženosti $i$ profitabilnosti. Rezultati istraživanja pokazuju da postoji statistički značajna korelacija $i$ linearan, negativan odnos pokazatelja zaduženosti u odnosu na profitabilnost posmatranih preduzeća. Rezultati istraživanja nisu pokazala nelinearan (konkavan) odnos. Istraživanje pokazuje i negativan $i$ statistički značajan uticaj materijalnosti imovine na profitabilnost velikih preduzeća u Srbiji, dok veličina preduzeća $i$ inflacija nemaju značajan uticaj na profitabilnost.

Ključne reči: zaduženost, profitabilnost preduzeća u Srbiji, GMM. 